\title{
Who is covered and who underreports: Access to social insurance on the Egyptian labor market
}

Irene Selwaness

Population Council

Rania Roushdy

Population Council

Follow this and additional works at: https://knowledgecommons.popcouncil.org/departments_sbsr-pgy

Part of the Demography, Population, and Ecology Commons, Family, Life Course, and Society Commons, and the Labor Economics Commons How does access to this work benefit you? Let us know!

\section{Recommended Citation}

Selwaness, Irene and Rania Roushdy. 2011. "Who is covered and who underreports: Access to social insurance on the Egyptian labor market," Gender and Work in the MENA Region Policy Brief. Cairo: Population Council. 
that exist in the metropolitan and the urban regions, relative to rural areas. It could also be due to how the urban
workers value social insurance relative to their rural counterparts. Finally, the likelihood of underreporting inworkers value social insurance relative to their rural counterparts. Finally, the likelihood of underreporting in-
creases with the worker's monthly basic salary. In other words, low-income workers may be paying contribution on their entire wage, while high-income workers are paying contributions on only a part of their wage.

Gender and marital status do not have any significant effect on the probability of having an underreported basic
wage to the social security authority. The probability of underreporting insurable wage decreases with educatio level. Compared to agriculture and fishing, the probability of underreporting among private sector wage worken of underreporting is significantly higher in the private sector, regardless of firm size, relative to the public secto of underreporting is significantly higher in the private sector, regardless of firm size, relative to the public sector
Within the private sector, this probabiliti is highest among workers of small size firms ( 10 or below) followed by
large size firms ( 50 and above), and is lowest among middle size firms.

Discussion and policy recommendations

The results presented in this bricf confirm several shortcomings of the Egyptian social insurance system, whic have been highlighted in the literature. First, the high social insurance contribution rates, requested from both the the peres a mas. port their wages in order to evade the high contributions they are paying. Also, by putting a maximum bound for te pensionable wage, the system loses a large part of the contributions that could have been collected from the th-income workers if there was no maximum ceiling on insurable earnings. Third, the fact that pension amoun 政 ervice to get high pensions. In other words, the way the pension is determined combined with weak law enforcment gives room for workers and employers to get around the system in order to pay lower contributions (Helmy
2008; Sieverding and Selwaness 2012). Prior to the January 25 th, 2011 revolution, a significant reform of the social insurance system was passed throug 2012; but due to the event of the revolution, the status of this law is still unclear

The essence of this new law is to remove the ceiling on pensionable wage and closely connect the worker paid
contributions during his her working years to what he/she gets as retirement pensions. This is a major change snce the earlier scheme only connected retirement payment to the last five years of contributions. This new system would create such a link through the use of notional accounts, which are virtual individual accounts that record employees' contributions throughout their period of service and then disperse them with interest at the

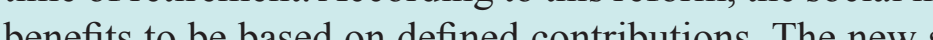

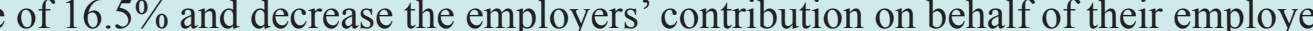
an average of $10 \%$. Employees would also have the right to pay higher contributions if they want. Under this

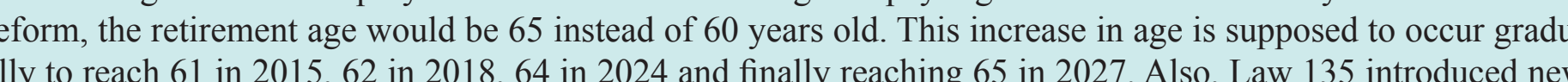

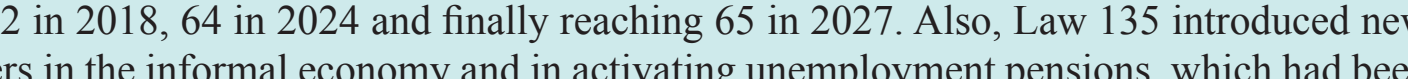
inactive in the earlier law (SSA 2011).

Hence, the law of 2010 was supposed to remedy many of the shortcomings of the original social insurance sys$\mathrm{em}$. Nevertheless, it is expected that the managing strategy of the notional accounts proposed under this new aw will be a mark of either success or failure of the new social insurance system. Also, an overall reduction in
both employers' and employees' contribution rates might be needed to encourage more participation, particularly both employers' and emplor
among the working poor.
A thorough evaluation of this new law combined with proper planning of its implementation is urgently needed. Finally, these reforms should be supported by a more rigorous enforcement of social insurance law and aware-
ness-raising campaigns of the benefits of social insurance and its system regulations, particularly among women
and youth.

\begin{tabular}{|c|}
\hline \\
\hline $\begin{array}{l}\text { y, O. 2008. “Towards a More Efficient and Equitable Pension System in Egypt," in The Egyptian Econ- } \\
\text { omy.: Current Challenges and Future Prospects, Hanaa Kheir-El-Din (Ed.), American University in } \\
\text { Cairo Press, pp. } 201-220 \text {. }\end{array}$ \\
\hline $\begin{array}{l}\text { International Labor Office ILO. 2009. “Building Adequate Social Protection Systems and Protecting People } \\
\text { in the Arab Region," Thematic Background Paper for the Arab Employment Forum, Arab Employ- } \\
\text { ment Forum, Beirut, 19-21 October. }\end{array}$ \\
\hline $\begin{array}{l}\text { Roushdy, R and I. Selwaness. 2012. “Who Is Covered and Who Underreports: An Empirical Analysis of } \\
\text { Access to Social Insurance on the Egyttian Labor Market," Gender and Work in the MENA Region } \\
\text { Working Paper Series, No. 25, Population Council, Egypt Country office }\end{array}$ \\
\hline $\begin{array}{l}\text { Sieverding, M. and I. Selwaness. 2012. "Social Protection in Egypt: A Policy Overview," Gender and Work in } \\
\text { the MENA Region Working Paper Series, No. 23, Population Council, Egypt Country office }\end{array}$ \\
\hline $\begin{array}{l}\text { Sieverding, M. 2012. "A Life Course Perspective on Social Protection among the Working Poor in Egypt,", } \\
\text { Gender and Work in the MENA Region Working Paper Series, No. 24, Population Council, Egypt } \\
\text { Country office }\end{array}$ \\
\hline $\begin{array}{l}\text { Social Security Administration (SSA). 2011. Social Security Programs around the World: Affica, 2011, So- } \\
\text { cial Security Administration. }\end{array}$ \\
\hline Era of Reform, Ragui Assaad (Ed.), American University in Cairo Press, pp. 131-157. \\
\hline \\
\hline
\end{tabular}

The Population Council confronts critical health and development issues-from stopping the spread of HIV to oimproving
reproductive health and ensuring that young people lead full and productive lives. Through biomedical, scoial science,

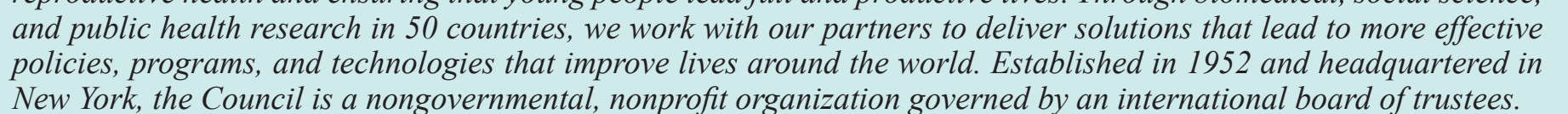
www.popcouncil.org

() 2012 The Population Council, Inc.
Irène Selwaness

Rania Roushdy

In Egypt, as in many developing countries, the convergence of poverty and lack of social security places the working
poor in a very vulnerable situation that mandates immediate action in research and programmatic interventions. Before the January 25 th revolution, a focus on social security was relevant in view of the inseceurities instigated by increasing market liberalization and the shrinking role
of the state in services and employment. The revolution and its aftermath heightened sense of insecurity and labor protests mandated a serious re-evaluation of
recent labor market policies and the social protection system in Egypt. This makes issues of social security, employment and household livelihood
particular relevance now more than ever:

This brief identifies the worker- and enterppise- level
dheterminants of having social insurance coverage o he Egyptian labor market among wage and non-wage workers. It also sheds light on the phenomenon of un derreporting of the basic salary to the social
authority in the private wage sector in Egypt.

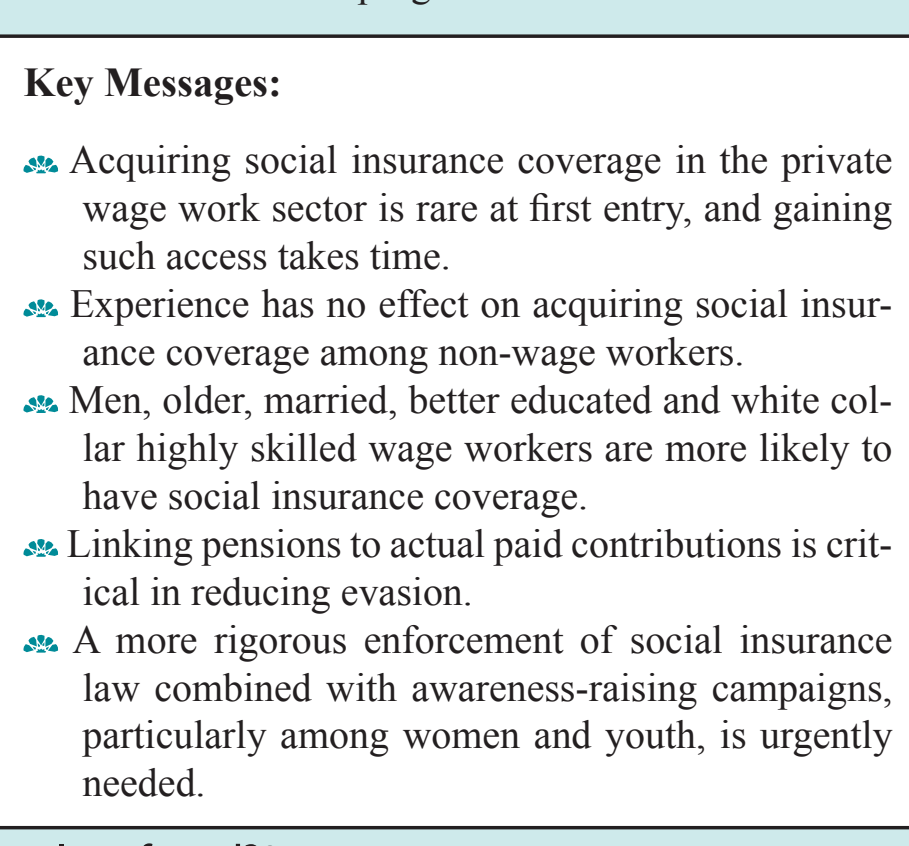
Social insurance system in Egypt: long established but poorly enforced?2

Egypt has a history of providing social security and social assistance projects. Following the socialist 1952 revolution employees pay their contributions that should be invested and repaid to them in the form of old age pensions. This sytem has gradually shifted to be a partially funded Pay-As-You-Go (PAYG) system with defined benefits (DB) scheme
Under this DB-PAYG scheme, the contributions of current active members are used to pay the pensions of the retired members, and the benefits are determinind as a
years before retirement (ILO 2009; SSA 2011).

Law 79 from 1975 draws the general scheme for the system, insuring all government, public sector and private sector employees. Contributions are deducted from two types of monthly wage earrings: the basic and the variable montt wages. ${ }^{3}$ The total monthly wage used for calculating contributions had a maximum ceiling of $1275 \mathrm{EGP}$ in $2006,1,925$
EGP in 2011 and is currently $2,100 \mathrm{EGP}$ (SSA 2011).45 Contributions are set as a fixed percentage of the pensionabl wage or the wage reported to the social insurance authority up to the determined ceiling levels. The total contribution

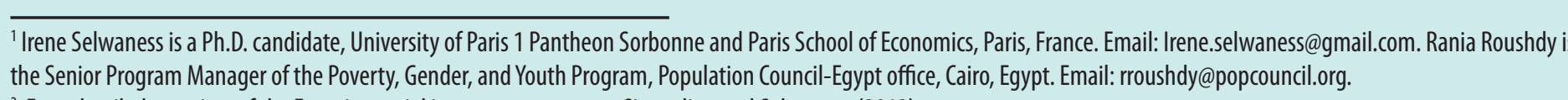

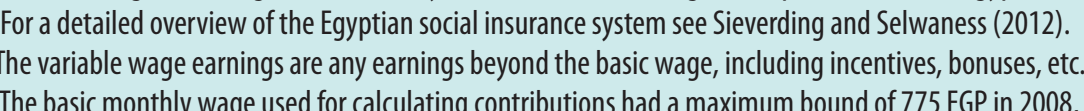

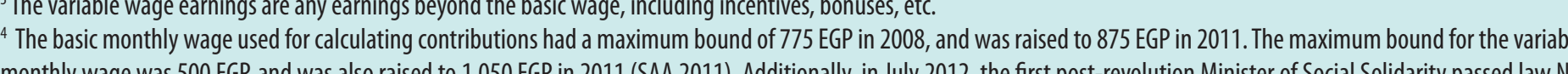

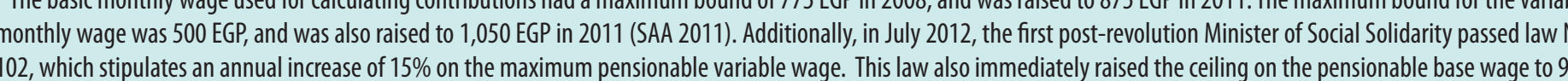

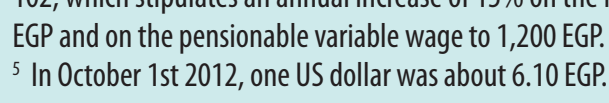

(2) Population Counc 
amounts to $41 \%$ of basic wage and $25 \%$ of variable wage, which is paid by employees, employers and the government.
Employees contribute $14 \%$ and $10 \%$ of their base and variable earnings, respectively; while employers contribute $26 \%$ and $15 \%$ of the base and variable earnings, respectively. The government contributes only $1 \%$ of the base wage in ad-
dition to covering any deficit in the system (Helmy 2004). Hence, these benefits are mainly financed by the employers and employees' contributions.

According to the law, participation of wage workers in the social security system is compulsory (79/1975) but volun
tary for non-wage workers (law 108/1976). Nevertheless, not all private sector employers follow the law. The high social insurance contribution rates required from employers cause many of them to either underreport the basic salary secther might minimize their opportunities of being employed in the public sector (Barsoum et al. 2009). Also, wage workes may negotiate with their employers for higher pay in return for not having social insurance. Many others are quite

Data and methods

The results presented in this brief are based on a study on the dynamics and determinants of access to social insurance on the Egyptian labor market (see Roushdy and Selwaness 2012 ). Using data from two rich nationally representative vey (ELMPS 06)-this stedy adderses wage underreported? The first question investigates the worker- and enterprise- level determinants of having access social insurance. The second question analyzes the risk of underreporting insurable wage to the social security autho-

How long it takes to get access to social insurance coverage?

Descriptive results show that wage workers are more likely to have social insurance compared to all types of non-wage workers, including employer, self-employed and unpaid amily workers. Access to social insurance among all work-
ers declined from about $52 \%$ in 1998 to less than $42 \%$ in 2006 (Figure 1). The observed decline in access to social insurance in 2006 has been fairly broad, cutting across both wage and non-wage workers. Nevertheless, this decline has been more prominent among employers (13 percentage pe
decline) relative to wage workers $(5$ percentage points decline).

igure 1: Percent of Workers (15-64 years old) who have Social Insurance Coverage by Employment St tus in 1998, and 2006

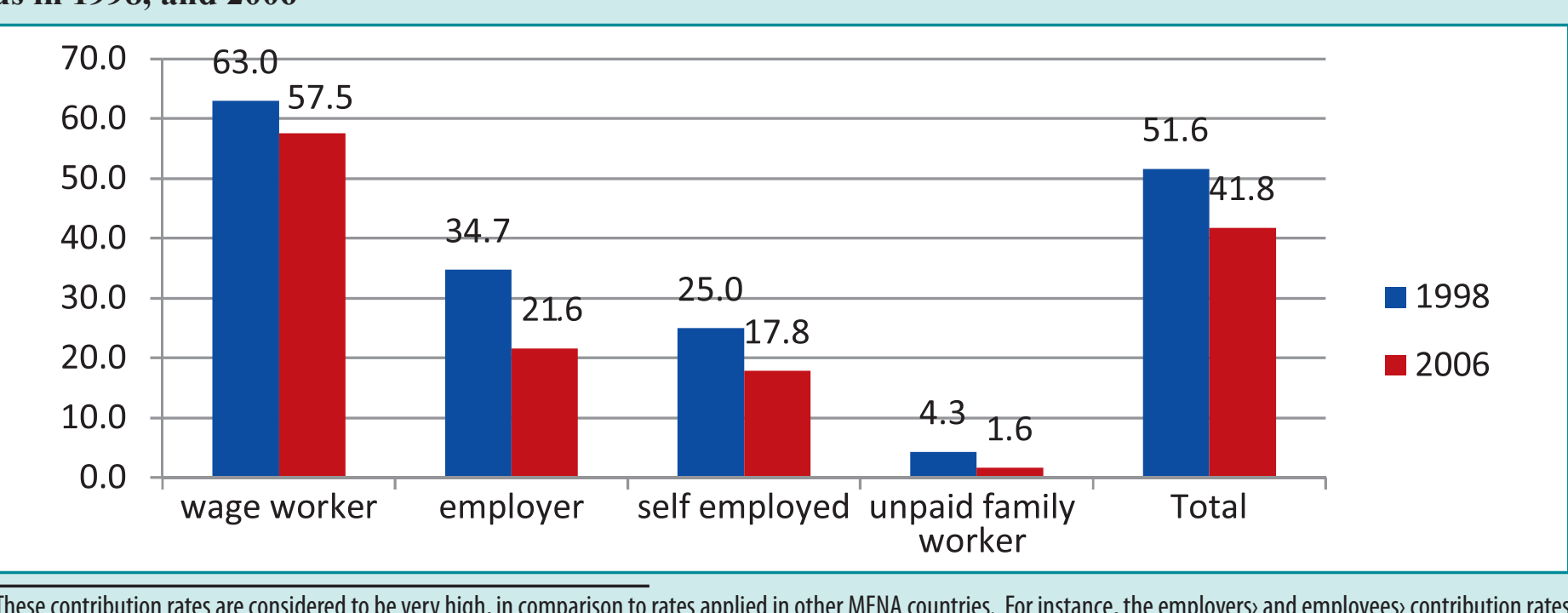

Focusing on wage workers, Figure 2 presents the percentage distribution of first jobs for wage workers by year of entry
into the labor market and sector of employment (public, private with social insurance coverage and private with no social insurance coverage), during the period 1960-2006. The figure confirms that following the guaranteed employto decline in favor of the informal private sector 9 The share of private sector wage workers who had access to social insurance during their first jobs, although growing, remains minimal. In contrast, uninsured wage employment has
been making up a substantial and growing share of total first jobs since late 1980s The share of private sector wage workers, who had no access to social insurance coverage during their first job sector in Egynt ot only in absorbing all new entrants after the shrinking role of the government sector but sector in Egypt, not only in absorbing all new entrants after $n$ ensuring formality or social security coverage to all its entrants.
ens.

Figure 2: Distribution of First Job by Year of Entry and Employment Status, Working Age Population $(15-64), 1960$ to 2005

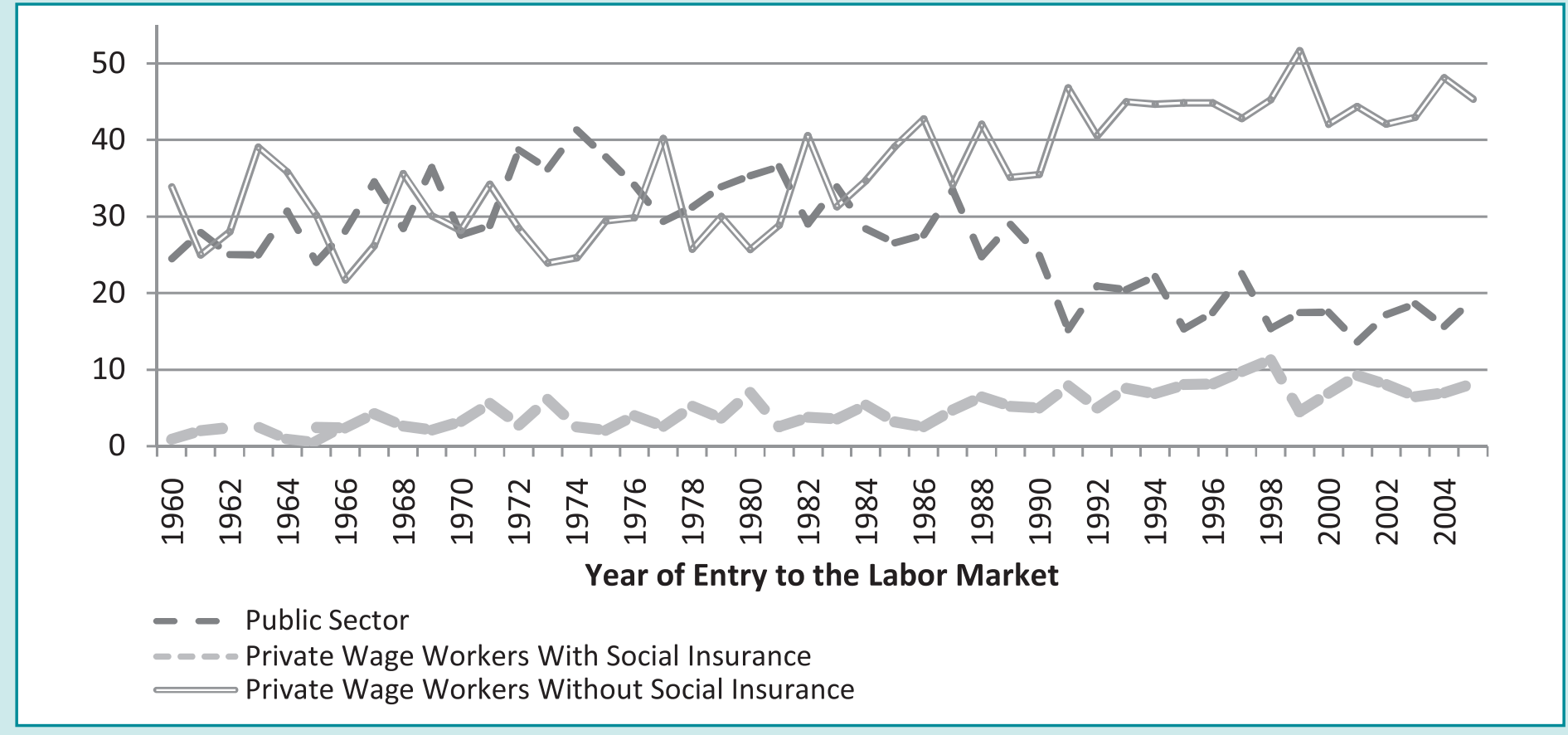

Figure 3 turns to exploring the role of job tenure in acquiring social insurance coverage. This figure compares
the share of the private sector wage workers who had no access to social insurance among

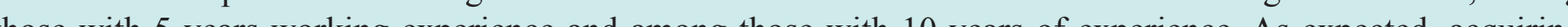
those with 5 years working experience and among those with 10 years of experience. As expected, acquiring
social insurance coverage in the private sector does not often come at first entry; gaining such access takes time The share of private sector wage workers with no social insurance is highest among labor market first entrants,
followed by those having 5 years of experience, and lowest among those with at least 10 years of working followed by those having 5 years of experience, and lowest among those with at least 10 years of working time among all the three working experience categories.

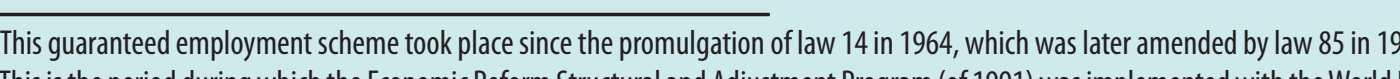

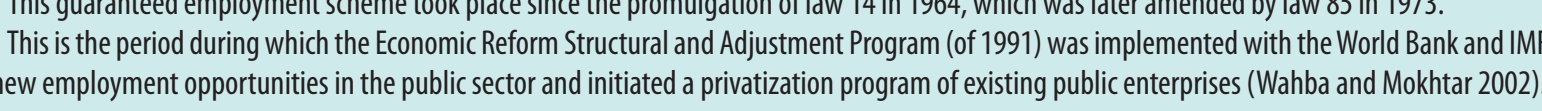

Figure 3: Distribution of Uninsured Private Sector Wage Workers by Job Tenure, Working Age Population

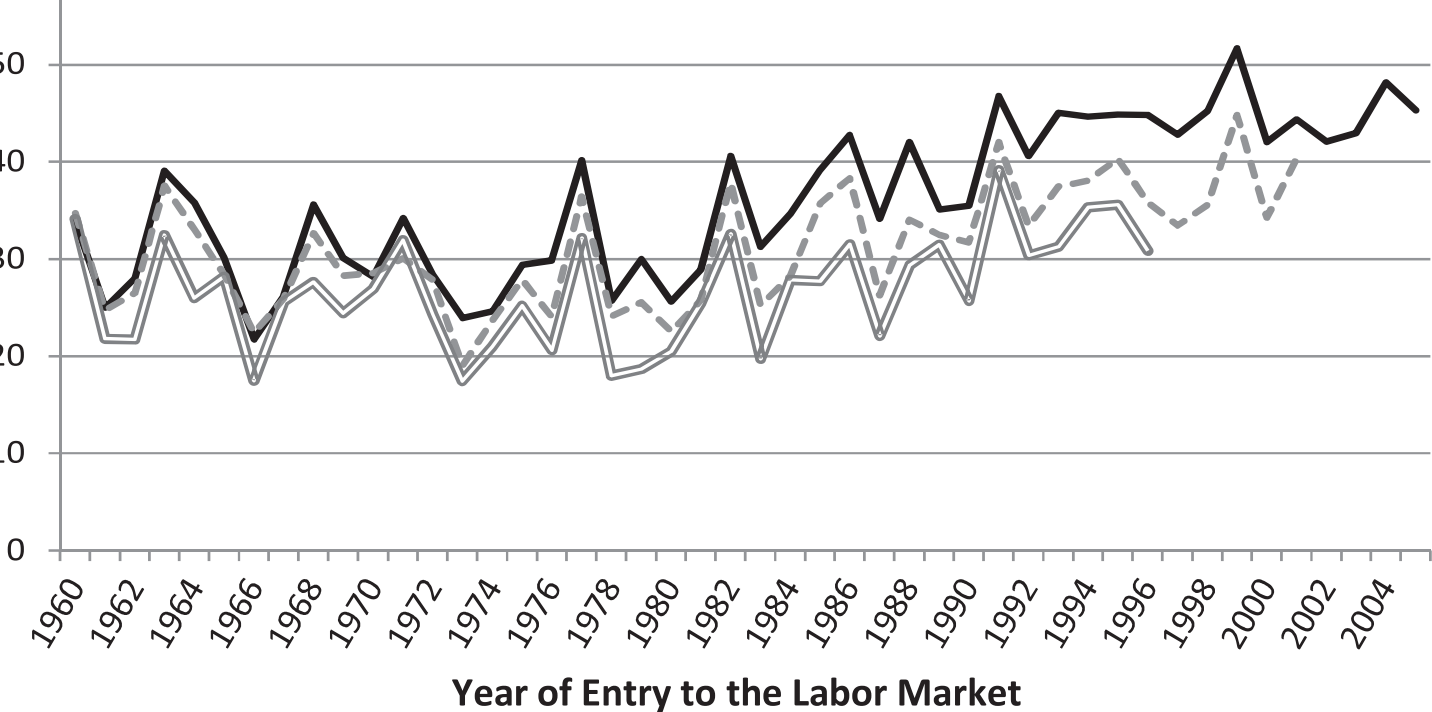

— First lob - Year of Entry to the Labor Market

Who gets social insurance, and where are the jobs offering social insurance coverage found? The multivariate analysis of the determinants of access to social insurance revealed that men and married wage
workers are more likely to have nificantly increases with education level. Blue collar workers are less likely to have access to social security comparison to white collar occupation groups. Furthermore, the presence of other socially insured members
the household positively increases the likelihood of having access to social insurance coverage. This might be the household positively increases the likelihood of having access to social insurance coverage. This might be
due to the spread of awareness regarding the importance of having social insurance and how to attain such access
among the household members.

The results among non-wage workers are slightly different than that of wage workers in terms of the impact of that experience on the job market is important for acquiring social insurance coverage among wage workers, but
has no effect among non-wage workers. Also, married wage workers are more likely to be covered, but marital
status does not affect access to social insurance among non-wage workers.

Access to social insurance for wage workers is more likely to exist in the public sector, in large private enterprises
and in the service economic activity group. Finally, working in rural Upper Egypt relative to Greater Cairo de-

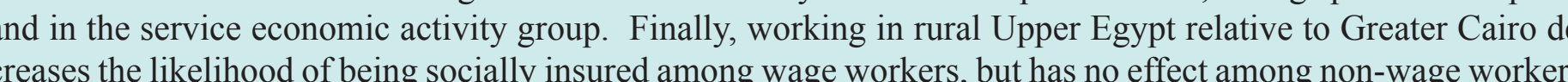
Who underreports basic salary?

In 2006, about $23 \%$ of wage workers had lower basic wage reported to the insurance system than they actually years to retirement age. In other words, workers tend to underreport their pensionable wage during their first yeas of service, and then fully report their wages near the end of their service. These results provide evidence to the fas that the way the pension is determined, based on the average monthly earnings during only the last few years Furthermore, enrolling employees in the social insurance system at a lower basic salary is more prevalent in rural
areas relative to the metropolitan governorates. This is probably due to the difference in law enforcement levels 